\title{
Optimalisasi Program Kartu Prakerja Dengan Pelatihan Branding Strategy
}

\author{
Rani Ika Wijayanti ${ }^{1}$, Ana Humardhiana ${ }^{2 *}$ \\ IAIN Syekh Nurjati Cirebon \\ 1e-mail: raniikawijayanti@gmail.com \\ 2e-mail: anahumardhiana@gmail.com \\ *Corresponding Author
}

\begin{abstract}
ABSTRAK
Pengangguran di Indonesia merupakan permasalahan yang tiap tahunnya semakin kompleks. Apalagi di masa pandemi Covid-19 ini yang membuat banyak perusahaan swasta terpaksa memPHK ratusan hingga ribuan karyawannya, yang menyebabkan semakin bertambahnya pengangguran di Indonesia. Oleh karena itu, pemerintah berupaya menyelesaikan permasalahan ini dengan segera. Salah satu upayanya yaitu dengan cara mengadakan Program Kartu Prakerja dimana pemegang kartu ini mendapatkan biaya pelatihan dari pemerintah untuk meningkatkan kompetensinya agar dapat diserap oleh perusahaan-perusahaan yang sesuai atau membuka lapangan usaha sendiri. Akan tetapi, masih banyak masyarakat (yang mengikuti program Kartu Prakerja ataupun tidak) yang bingung untuk memulai dari mana dan bagaimana mereka harus bekerja. Oleh karena itu, tujuan dari pengabdian masyarakat ini yaitu mengoptimalisasikan Program Kartu Prakerja dengan memberikan pelatihan Branding Strategy bebas biaya agar para pemegang Kartu Prakerja, yang belum lolos mendapatkan Kartu Prakerja, dan masyarakat pada umumnya dapat melangkah dengan mantap dalam memasarkan produknya yang berupa barang dan/ataupun jasa.
\end{abstract}

Kata kunci: Pengangguran, Kartu Prakerja, Branding Strategy

\begin{abstract}
Unemployment in Indonesia is an increasingly complex problem year by year. Moreover, during the Covid-19 pandemic, many private companies have no choice but to lay off hundreds to thousands of their employees, leading to increasing unemployment in Indonesia. Therefore, the government is trying to resolve this problem immediately. One of the efforts is by organizing Program Kartu Prakerja (the Pre-Employment Card Program) in which the cardholders receive training costs from the government to increase their competency so that they can be absorbed by the appropriate companies or open their own business fields. However, there are still many people (whether or not they participate in the Employment Card program) who are confused about where and how to start. Therefore, the purpose of this community service is to optimize Program Kartu Prakerja by providing free Branding Strategy training in order that holders of Kartu Prakerja, those who have not passed the Program Kartu Prakerja, and the general people can take their first steady steps in marketing their products in the forms of goods and/or services.
\end{abstract}

Keywords: Unemployment, Kartu Prakerja, Branding Strategy 


\section{PENDAHULUAN}

Permasalahan pengangguran di Indonesia merupakan permasalahan yang menahun yang harus dihadapi negara Indonesia. Jumlah angka pengangguran pun relatif semakin meningkat tiap tahunnya. Menurut data BPS (Badan Pusat Statistik), angka pengangguran di Indonesia per Agustus 2019 mencapai 5,01 dan merupakan yang tertinggi kedua di negara Asia Tenggara, setelah Filipina. Padahal jika dilihat, jumlah penduduk usia produktif di Indonesia mencapai setengah dari total jumlah penduduk yang ada. Meskipun hal ini dialami negara Indonesia sebelum adanya pandemi global Covid-19, yang juga melanda negara-negara lain, dapat diperkirakan selama dan beberapa bulan setelah pandemi angka pengangguran di Indonesia bertambah drastis. Hal ini dikarenakan banyaknya UMKM dan perusahaan-perusahaan yang mengalami kerugian sehingga mengharuskan mereka memulangkan atau mem-PHK karyawannya dan gulung tikar.

Menurut Sadono Sukirno dalam (Pitartono, 2012), pengangguran sendiri adalah seseorang yang sudah digolongkan dalam angkatan kerja yang secara aktif sedang mencari pekerjaan pada suatu tingkat upah tertentu, tetapi tidak dapat memperoleh pekerjaan yang diinginkannya. Sementara menurut (Marius, 2004), pengangguran sering diartikan sebagai angkatan kerja yang belum bekerja atau bekerja secara tidak optimal. Di artikel ini, pengangguran merupakan sebuah istilah yang merujuk ke seseorang yang tidak bekerja sama sekali, sedang mencari pekerjaan, bekerja kurang dari dua hari per minggunya, atau seseorang yang sedang berusaha mendapatkan pekerjaan yang layak. Ada beberapa faktor penyebab pengangguran, antara lain yaitu sulitnya memperoleh lapangan pekerjaan, kurangnya persyaratan pelamar kerja, perkembangan atau pergantian teknologi tanpa adanya pelatihan atau kemampuan yang tepat bagi pekerja sehingga menimbulkan PHK, kemunduran ekonomi yang menyebabkan perusahaan memutuskan untuk PHK, siklus ekonomi yang berfluktuasi karena pergantian musim, dan tidak adanya lapangan kerja yang sesuai dengan bidang keahlian.

Dilihat dari keadaan yang menyebabkannya, pengangguran dibedakan menjadi 3 jenis (Sukirno, 2004), yaitu:

\section{Pengangguran friksional (frictional unemployment)}

Pengangguran friksional yaitu pengangguran yang disebabkan oleh tindakan seorang pekerja yang meninggalkan pekerjaannya dan mencari pekerjaan yang lebih baik atau sesuai dengan keinginannya. Sebenarnya ada beberapa lapangan pekerjaan yang menginginkan jasa dari tenaga kerja tersebut tetapi sifat memilih pekerjaan yang menyebabkan tenaga kerja menjadi pengangguran friksional. 


\section{Pengangguran struktural (structural unemployment)}

Pengangguran struktural yaitu pengangguran yang disebabkan oleh adanya perubahan struktur dalam perekonomian. Pada umumnya, negara berupaya mengembangkan perekonomian dari pola agraris ke industrial. Dan hal ini dapat memicu naiknya angka pengangguran struktural.

3. Pengangguran konjungtur atau siklikal atau siklus

Pengangguran konjungtur adalah pengangguran yang disebabkan oleh kelebihan pengangguran alamiah dan berlaku sebagai akibat pengurangan dalam permintaan agregat. Pengangguran ini terjadi karena adanya gelombang konjungtur, yaitu adanya resesi atau kemunduran dalam ekonomi. Misal, suatu perusahaan akan merekrut banyak tenaga kerja ketika sedang maju. Tetapi ketika sedang merugi, perusahaan tersebut akan mem-PHK banyak tenaga kerja juga yang menyebabkan terjadinya pengangguran.

Seperti 3 jenis pengangguran di atas, (Marius, 2004) juga menambahkan jenis pengangguran berdasarkan penyebabnya:

1. Pengangguran musiman (seasonal unemployment)

Pengangguran jenis ini disebabkan karena adanya perubahan musim. Misalnya, seorang petani yang terpaksa menganggur ketika bukan musim bertani dan panen.

2. Pengangguran teknologi

Pengangguran teknologi yaitu pengangguran yang disebabkan oleh perkembangan atau pergantian teknologi. Perubahan ini dapat menyebabkan pekerja harus diganti untuk bisa menggunakan teknologi yang diterapkan.

3. Pengangguran politis

Pengangguran politis yaitu pengangguran yang dikarenakan oleh adanya peraturan pemerintah yang secara langsung ataupun tidak dapat mengakibatkan pengangguran.

4. Pengangguran deflatoir

Pengangguran jenis ini disebabkan oleh tidak cukup tersedianya lapangan pekerjaan dalam perekonomian secara keseluruhan, atau karena jumlah tenaga kerja melebihi kesempatan kerja.

(Marius, 2004), yang melihat pengangguran sebagai angkatan kerja yang belum bekerja atau bekerja secara tidak optimal, juga membedakan pengangguran menjadi 3 macam, yakni:

1. Pengangguran terbuka (open unemployment)

Pengangguran terbuka adalah tenaga kerja yang betul-betul tidak mempunyai pekerjaan. Hal ini dikarenakan 2 hal, yaitu (1) mereka belum mendapatkan pekerjaan meskipun telah berusaha semaksimal mungkin untuk mendapatkan pekerjaan dan (2) mereka malas mencari pekerjaan atau malas bekerja. 
2. Pengangguran terselubung (disguised unemployment)

Pengangguran terselubung merupakan pengangguran yang terjadi karena terlalu banyaknya tenaga kerja untuk satu unit pekerjaan padahal dengan mengurangi tenaga kerja tersebut sampai jumlah tertentu tetap tidak mengurangi jumlah produksi. Pengangguran terselubung bisa juga terjadi karena tenaga kerja bekerja tidak sesuai bakat dan kemampuannya, akhirnya bekerja tidak optimal.

3. Setengah menganggur (under unemployment)

Pengangguran jenis ini yaitu tenaga kerja yang tidak bekerja secara optimal karena tidak ada pekerjaan untuk sementara waktu. Misalnya, seorang buruh bangunan yang telah menyelesaikan pekerjaan di suatu proyek, untuk sementara menganggur sambil menunggu proyek berikutnya.

Dengan semakin bertambahnya jumlah pengangguran di Indonesia, maka pemerintah perlu mempercepat pelaksanaan pengentasan pengangguran ini. Adapun salah satu upaya pemerintah yaitu dengan mengeluarkan program Kartu Prakerja.

Seperti yang dilansir di situs resminya, www.prakerja.go.id, Kartu Prakerja adalah program pengembangan kompetensi berupa bantuan biaya yang ditujukan untuk pencari kerja, pekerja ter-PHK, atau pekerja yang membutuhkan peningkatan kompetensi. Program ini merupakan kolaborasi pemerintah dengan pihak swasta yang didesain sedemikian rupa untuk memberikan nilai kepada pengguna dan juga memberikan nilai kepada sektor swasta. Dengan mengikuti program ini, para pemegang Kartu Prakerja akan mendapatkan bantuan biaya total mencapai Rp.3.550.000,00, dengan rincian biaya pelatihan Rp.1.000.000,00 untuk 3 kali kursus, Rp.2.400.000,00 untuk bantuan manfaat yang dibagi 4 bulan, dan Rp.150.000,00 untuk insentif pengisian survei yang dibagi 3 kali pencairan. Ada 8 mitra platform digital yang ditunjuk pemerintah untuk memberikan pelatihan-pelatihan kepada pemegang Kartu Prakerja, yaitu Tokopedia, Bukalapak, Skill Academy, Kemnaker, Pintaria, Pijar, Sekolah.mu, dan MauBelajarApa. Terdapat ratusan pelatihan yang ditawarkan oleh kedelapan mitra platform digital tersebut untuk meningkatkan kompetensi yang dapat dipilih oleh para pemegang Kartu Prakerja. Pelatihan ini bersifat offline dan online. Akan tetapi, di masa pandemi ini, pemerintah untuk sementara waktu hanya membuka pelatihan yang bersifat online. Program Kartu Prakerja ini dibuka dengan beberapa gelombang sejak tanggal 11 April 2020 dan sudah ada lebih dari 8 juta orang yang mendaftar per 27 April 2020.

Lalu bagaimana cara mendapatkan dan memanfaatkan Kartu Prakerja? Sebelum mengikuti prosesnya, perlu diketahui bahwa syarat utama untuk mengikuti program ini adalah Warga Negara Indonesia yang berusia 18 tahun ke atas dan tidak sedang sekolah ataupun kuliah. Langkah pertama 
yang harus dilakukan yaitu mendaftar di situs resmi Kartu Prakerja yaitu www.prakerja.go.id dengan memasukkan data diri untuk diverifikasi. Langkah kedua yaitu calon peserta harus mengikuti tes pendek kemampuan dasar maupun motivasi. Ketiga, calon peserta menunggu pengumuman peserta yang diterima. Keempat, peserta yang lolos bisa ke platform digital mitra Kartu Prakerja untuk memilih pelatihan yang diinginkan. Kelima, peserta mengikuti pelatihan online sesuai pilihan. Keenam, setelah menyelesaikan pelatihan, peserta akan mendapatkan sertifikat elektronik dan lembar survei terkait program pelatihan yang diikuti, serta mendapatkan insentif Rp.150.000,00 setelah pengisian survei evaluasi tersebut. Terakhir, peserta akan menerima insentif sebesar Rp.600.000,00 per bulan selama 4 bulan setelah menuntaskan pelatihan.

Meskipun sudah ada lebih dari 8 juta orang yang mendaftar, tidak semuanya dapat lolos dan mendapatkan Kartu Prakerja. Ada yang gagal dan harus menunggu gelombang berikutnya untuk mendaftar lagi. Ada juga yang masih bingung harus memulai dari mana kendati sudah mengikuti pelatihan. Rata-rata mereka bingung bagaimana cara membangun citra diri untuk mulai bekerja. Sejatinya ketika seseorang mencari kerja ataupun membuka lapangan kerja, ia akan mencoba memasarkan kompetensi ataupun produk yang dimilikinya. Oleh karena itu, penting sekali untuk para pemegang Kartu Prakerja (dan/atau yang belum lolos mendapatkan Kartu Prakerja, juga masyarakat pada umumnya) mempelajari branding strategy agar jasa atau produk yang akan dijualnya dapat terpasarkan dengan baik.

Dalam pengabdian ini, kami berupaya membantu pemerintah dengan mengadakan pelatihan Branding Strategy bebas biaya untuk para pemegang Kartu Prakerja yang sudah menyelesaikan pelatihan, pendaftar program Kartu Prakerja yang belum bisa lolos, dan masyarakat umum lainnya yang sedang mencari ataupun membuat lapangan pekerjaan. Adapun rumusan masalah dalam pengabdian ini yaitu: (1) "Bagaimana bentuk pelatihan Branding Strategy bebas biaya untuk para pemegang Kartu Prakerja yang sudah menyelesaikan pelatihan, pendaftar program Kartu Prakerja yang belum bisa lolos, dan masyarakat umum lainnya yang sedang mencari ataupun membuat lapangan pekerjaan?"; dan (2) "Bagaimana pengaruh pelatihan tersebut kepada peserta pelatihan?"

\section{BAHAN DAN METODE}

Dalam kegiatan pengabdian masyarakat ini, kami telah menentukan target peserta pelatihan dan metode dalam menyampaikan materi. Target peserta yang kami tuju adalah Warga Negara Indonesia yang telah mendaftar Program Kartu Prakerja, pemegang Kartu Prakerja, dan yang belum lolos mendapatkan Kartu Prakerja. Selain itu, masyarakat umum dengan rentang usia 18- 
25 tahun yang ingin berwirausaha namun masih mengalami kesulitan untuk memulai membuat sebuah brand diperkenankan mengikuti pelatihan ini.

Materi yang disampaikan dalam rangka kegiatan pengabdian masyarakat ini meliputi pengenalan dasar tentang strategi branding (branding strategy) untuk usaha mikro. Tujuan yang diharapkan dari strategi ini adalah para peserta dapat memahami dasar-dasar untuk membentuk sebuah brand. Sarana penyampaian materi yang kami gunakan adalah dengan memanfaatkan media sosial Instagram melalui fitur live video. Selama program pelatihan berlangsung, mentor akan menyampaikan materi-materi secara live atau siaran langsung. Interaksi antara mentor dan peserta dapat terjadi secara real time. Manfaat lain yang dapat diambil dari penggunaan media sosial Instagram adalah jangkauan area yang luas selama terhubung dengan internet sekaligus mematuhi anjuran pemerintah untuk melakukan physical distancing dalam masa pandemi Covid19. Setelah para peserta mengikuti sesi pertama materi melalui Instagram, kami akan melakukan pendampingan sebagai tahap lanjutan. Dalam kegiatan ini, para peserta akan tergabung dalam WhatsApp Group yang digunakan sebagai media untuk sharing dan konsultasi baik dengan para mentor maupun sesama peserta.

\section{HASIL DAN PEMBAHASAN}

\section{Proses Pelatihan dan Materi yang Digunakan}

Harold Laswell mengemukakan sebuah model komunikasi yang berbunyi, "Who said what in which channel to whom with what effect?" (Sapienza et al., 2015). Komunikasi pemasaran adalah suatu bentuk komunikasi yang dilakukan untuk menyampaikan pesan tentang sebuah produk atau jasa dengan menerapkan strategi tertentu agar mendapatkan respon yang diinginkan dari konsumen yang dituju. Karena untuk menumbuhkan kesadaran, memperkenalkan hingga terjadinya tindakan jual beli antara konsumen dan produsen melalui sarana komunikasi bukanlah sebuah hal yang mudah (Prisgunanto, 2006).

Kami mengidentifikasi dua permasalahan utama yang sering dihadapi oleh calon-calon entrepreneur yang menjadi peserta dalam pelatihan ini. (1) Peserta pelatihan ingin membuat sebuah usaha namun sama sekali belum mengetahui dasar maupun langkah-langkah yang harus ditempuh untuk mewujudkannya. (2) Peserta pelatihan sudah mengetahui usaha apa yang akan ia kembangkan namun masih ada kendala yang dihadapi ketika mewujudkan keinginannya. Melalui kegiatan pengabdian masyarakat ini, kami ingin mengedukasi mereka dengan mengadakan pelatihan branding strategy. Dengan adanya branding, maka produk yang dihasilkan akan menjadi mudah dikenali, diingat dan bersaing (Ardi et al., 2017). 
Sebuah brand atau yang bisa disebut dengan merk dapat menciptakan identitas sebuah produk. Dengan menyusun strategi yang baik, produsen akan mampu meningkatkan penjualan, menarik konsumen, memperluas jangkauan distribusi, membentuk image yang baik sehingga terbentuk brand loyalty. Pelatihan branding strategy yang kami laksanakan ini berdasarkan pada bauran komunikasi pemasaran atau Marketing Mix. Kami menggunakan pendekatan 4P untuk menjelaskan konsep dari Marketing Mix tersebut menjadi Product, Price, Place, dan Promotion. Keempat hal tersebut menjadi kerangka untuk mengidentifikasi, mengelola, dan menggabungkan kegiatan pemasaran. "Pemasaran adalah suatu proses sosial yang di dalamnya individu dan kelompok mendapatkan apa yang mereka butuhkan dan inginkan dengan menciptakan, menawarkan, dan secara bebas mempertukarkan produk yang bernilai dengan pihak lain” Kotler dan Keller dalam (Lestari, 2015).

\section{Product}

Produk dapat digolongkan menjadi sebuah barang maupun jasa yang dibutuhkan oleh masyarakat. Sebagai seorang produsen, penjual, atau penyedia layanan juga harus mampu mengenali peluang-peluang apa saja yang tersedia. Berbagai barang maupun jasa yang saat ini tersedia di pasar "ada" karena permintaan dari para konsumen. Untuk mengetahui keinginan dan kebutuhan masyarakat, hendaknya para produsen melakukan riset sebelum melaunching produk tersebut ke pasar.

Persaingan yang ketat antar pengusaha, faktor ekonomi, waktu, tempat, dan faktorfaktor lainnya menuntut para produsen, penjual, atau penyedia layanan untuk sekreatif mungkin menciptakan produk barang atau jasa yang akan ditawarkannya. Penting sekali untuk menemukan ciri khas yang akan menjadi sebuah identitas produk tersebut dan memiliki kelebihan yang tidak ada dipunyai kompetitor. Selain itu, nama atau merk dagang adalah salah satu hal yang penting. Nama inilah yang akan terus melekat kepada produk dan membuat konsumen lebih aware dan mampu mempengaruhi konsumen untuk mengingat hingga membeli produk tersebut. Nama atau merk dagang dapat dibuat sekreatif mungkin dan mudah diingat oleh konsumen.

Indonesia terdiri dari banyak suku bangsa, wilayah yang luas, dan kebudayaan yang beranekaragam. Hal ini menyebabkan kebutuhan-kebutuhan konsumen menjadi sangat variatif. Sebuah produk tidak lantas mampu memenuhi seluruh kebutuhan konsumen dari seluruh wilayah Indonesia, maka diperlukan segmentasi pasar. Definisi dari segmentasi pasar adalah langkah-langkah yang terpadu untuk mengelompokkan pasar yang cenderung heterogen menjadi sub bagian atau segmen yang lebih homogen dan signifikan (Kayode, 2014). Terdapat tiga jenis segmentasi pasar yang biasa dilakukan, antara lain: 
a. Demografis: segmentasi pasar dengan mengelompokkan konsumen menjadi kelompokkelompok tertentu seperti umur, jenis kelamin, pendapatan, pekerjaan, dan lain sebagainya.

b. Geo-Demografis: segmentasi pasar dengan melihat dimana tempat tinggalnya

c. Psikografis: segmentasi pasar dengan mengelompokkan konsumen berdasarkan nilai, kepribadian, minat, dan sebagainya

Peserta pelatihan diajak untuk mengenali potensi dari faktor internal dan eksternal terkait produk yang akan mereka wujudkan. Harapannya, mereka akan mampu untuk mengidentifikasi kekuatan-kekuatan tersebut dan meminimalisir kelemahan yang dimiliki untuk mendukung langkah-langkah selanjutnya yang akan melengkapi dari unsur pertama di atas.

2. Price

Price atau harga adalah salah satu unsur penting dalam Marketing Mix. Harga sebuah produk pada dasarnya merupakan sejumlah uang yang harus dikeluarkan oleh konsumen untuk dapat menikmati produk yang ditawarkan. Menentukan besaran harga pada sebuah produk dianggap bukan hal yang mudah, karena harga dapat menentukan keuntungan dan kelanggengan usaha. Harga juga dapat membentuk persepsi di benak konsumen terkait produk yang dijual. Seringkali sebuah produk yang memiliki harga murah dianggap berkualitas rendah dibandingkan produk milik competitor. Namun harga jual yang tinggi lantas tidak serta merta produk tersebut dianggap memiliki kualitas tinggi.

Peserta pelatihan diajak untuk mengenali produk yang akan mereka wujudkan dan menentukan harga yang tepat. Harapannya, mereka akan mampu untuk bersaing dengan kompetitor dari segi harga produk dan untuk mendukung langkah-langkah selanjutnya yang akan melengkapi dari unsur kedua di atas.

3. Place

Place dapat diartikan sebagai tempat, saluran, atau posisi di mana produk yang dibuat oleh produsen. Peserta pelatihan diajak untuk mengidentifikasi berbagai kelebihan dan kekurangan menjual produk di tempat yang berupa fisik maupun non fisik, atau yang saat ini dikenal dengan sebutan toko offline dan toko online. Perubahan pola konsumsi dan komunikasi di masyarakat juga membuat toko offline dan toko online bersaing mengembangkan usahanya. Masing-masing metode penjualan memiliki kelebihan dan kekurangan masing masing.

a. Toko Offline

- Kelebihan: 
1) Pengalaman berbelanja secara langsung inilah yang tidak dapat tergantikan. Toko offline masih memiliki peminat di tengah menjamurnya toko online. Konsumen dapat melihat, memilih, mencoba, dan membandingkan produk secara langsung. Akibat maraknya penipuan yang terjadi ketika membeli barang secara online, memiliki toko offline juga sering dijadikan suatu faktor untuk menilai brand tersebut kredibel atau tidak.

2) Toko offline memudahkan proses pelayanan karena penjual dan pembeli berada dalam suatu waktu yang sama. Toko offline juga dapat menyediakan layanan customer service secara langsung, misalnya menangani komplain, menjawab pertanyaan-pertanyaan dari konsumen, dan sebagainya.

3) Transaksi keuangan menggunakan uang tunai dinilai lebih aman dalam proses jualbeli produk. Pembeli dan penjual sama-sama dapat mengurangi resiko akibat penipuan atau adanya kendala lain yang disebabkan gangguan pada sistem pembayaran secara online.

4) Proses jual-beli di toko offline tidak memerlukan pengiriman barang. Penjual tidak diributkan dengan proses pengemasan dan pengiriman barang yang memakan waktu dan biaya lebih. Selain itu, pembeli juga tidak perlu menunggu barang yang dipesan tiba.

5) Toko offline sudah memiliki pelanggan loyal dan persaingan antara toko-toko offline tidak seketat persaingan di dunia jual-beli online.

- Kekurangan:

1) Daya jangkau toko offline terbatas di lingkungan sekitarnya. Untuk itu faktor pemilihan lokasi yang strategis menjadi poin penting untuk memasarkan produk dengan menerapkan strategi-strategi lain untuk merangkul konsumen yang lebih luas.

2) Toko offline memerlukan tempat fisik yang digunakan untuk proses jual-beli, pelayanan, maupun penyimpanan. Perawatan bangunan juga memerlukan usaha yang lebih agar toko mampu bertahan lama dan tidak lupa membuat visualisasi yang menarik.

3) Untuk melaksanakan penjualan secara offline, dibutuhkan dukungan SDM yang mencukupi. Sebagai seorang pemilik bisnis harus mengeluarkan biaya dan waktu yang lebih dalam proses perekrutan dan pelaksanaan kegiatan sehari-hari.

4) Toko offline memiliki jam operasional yang terbatas sekitar 10-12 jam dalam sehari. 
5) Toko offline memiliki keterbatasan dalam stok barang. Jika toko tersebut tidak memiliki atau kehabisan stok, maka pembeli akan sulit untuk mendapatkan produk tersebut secara langsung dan kemudian berpindah ke toko lain.

Dari poin-poin yang telah disebutkan di atas, toko offline memerlukan modal yang lebih besar untuk menyediakan lokasi fisik, stok produk, biaya perawatan, dan biaya untuk menggaji karyawan. Maka modal usaha haruslah diperhitungkan dengan matang sebelum membuka toko offline.

\section{b. Toko Online}

\section{- Kelebihan:}

1) Perkembangan dunia digital yang sangat pesat adalah salah satu faktor mengapa toko online sangat banyak bermunculan. Untuk membuat sebuah toko online sangatlah mudah dan cukup berbekal gadget saja. Dengan adanya dukungan dari media sosial atau market place, siapa saja dan dari lapisan masyarakat manapun memiliki kesempatan yang sama untuk memulai berwirausaha.

2) Jangkauan internet yang sangat luas serta tidak terhalang batasan waktu dan tempat, memudahkan penjual untuk memasarkan produknya. Produk tersebut dapat dipasarkan hingga ke luar area lokal dan dapat pula menembus pasar nasional dan internasional.

3) Membuka toko online tidak memerlukan modal yang terlalu besar seperti membuka toko offline. Banyak faktor-faktor yang dapat mengurangi besarnya modal tersebut, misalnya: a.) Penjual tidak perlu menyiapkan toko fisik untuk melakukan kegiatan jual-beli, pelayanan, dan penyimpanan produk; b.) Penjual hanya memerlukan modal sedikit bahkan tidak perlu menyediakan modal untuk memproduksi produk yang ditawarkan. Karena model bisnis online dapat dilakukan secara reseller dan dropship. Untuk sistem reseller, penjual hanya perlu menyediakan stock barang yang tidak terlalu banyak. Lalu untuk sistem dropship, penjual tidak perlu memiliki stock produk dan melakukan pengiriman, namun hanya dengan mepromosikan produk dan melakukan kegiatan pemasaran saja selebihnya dilakukan oleh agen; dan c.) Penjual memerlukan karyawan yang lebih sedikit atau bahkan tidak memerlukan karyawan sama sekali sehingga dapat menekan biaya operasional.

4) Kegiatan jual-beli di toko online dapat berlangsung selama 24 jam.

5) Produk yang dijual melalui toko online sangat bervariasi. Dengan waktu yang terhitung singkat, pembeli bisa mendapatkan berbagai barang yang dibutuhkan dari berbagai agen yang tersedia. 
- Kekurangan:

1) Persaingan yang ketat di antara penjual toko online membuat masing-masing toko berlomba-lomba untuk menjual produknya dengan berbagai macam strategi. Selain itu, pengusaha online juga bersaing dengan pemilik toko-toko lain di lingkup nasional maupun internasional.

2) Akibat maraknya penipuan yang melibatkan bisnis online, maka kredibilitas usaha online ini sering diragukan. Misalnya, keberadaan dan bentuk fisik barang yang tidak dapat dipegang secara langsung oleh konsumen sering menimbulkan celah untuk kecurangan. Kemudian adanya transaksi fiktif hingga penggelapan uang konsumen juga menjadi kendala yang sering ditemui dalam bisnis online.

3) Konektivitas internet yang kurang mumpuni juga menjadi kendala dalam bisnis online. Pemilik toko dapat mengalami kerugian dan pembeli dapat lebih mudah beralih ke toko lain yang memiliki respon lebih cepat. (No Title, n.d.) (https://www.jurnal.id/id/blog/toko-offline-vs-online-kelebihan-kekurangannya/)

Peserta pelatihan diajak untuk mengidentifikasi dan menentukan metode berjualan yang akan dilakukan. Apakah mereka akan memilih jalur offline atau online untuk usahanya. Harapannya, mereka akan mampu mengelola usahanya dengan tepat melalui jalur manapun yang mereka pilih, mampu memunculkan potensi untuk mendukung langkah-langkah selanjutnya yang akan melengkapi dari unsur ketiga di atas.

\section{Promotion}

Promosi merupakan langkah atau strategi yang disusun secara sistematis untuk menumbuhkan awareness dan interest demi terlaksananya sebuah proses pembelian atau purchase. Tujuan promosi adalah memberikan informasi, mempengaruhi konsumen dan mengingatkan tentang produk dan perusahaan kepada konsumen (Kotler, 2003). Strategi promosi yang dapat digunakan oleh para pengusaha antara lain periklanan, public relation, sales promotion, direct marketing, dan personal selling atau yang disebut dengan promotion mix (Kitchen, 2002). Strategi promosi harus ditentukan secara spesifik agar pengkoordinasian kelima unsur di atas menjadi sebuah strategi yang efektif dan efisien.

Definisi unsur bauran promosi tersebut adalah sebagai berikut:

a. Periklanan (advertising): sebuah rencana yang terstruktur meliputi target strategi, tampilan, tema, jadwal, biaya, dan metode yang dibuat untuk mendapatkan hasil yang diinginkan. 
b. Promosi penjualan (sales promotion): sebuah rencana yang terstruktur untuk menjual produk atau pelayanan untuk mencapai hasil yang diinginkan.

c. Public Relation: upaya-upaya yang dilakukan oleh produsen secara terpadu untuk menganalisis tren, manajemen organisasi, dan melaksanakan program lain yang berorientasi kepada pelayanan untuk konsumen.

d. Pemasaran langsung (direct marketing): sebuah usaha yang dilakukan dengan target pelanggan individu dengan tujuan menyampaikan informasi secara pribadi dan membangun relasi dengan mereka berdasarkan respon yang ada terhadap langkahlangkah komunikasi yang telah dilakukan.

e. Personal selling: langkah-langkah komunikasi secara verbal dalam bentuk percakapan dengan konsumen untuk tujuan penjualan.

Peserta pelatihan diajak untuk mengidentifikasi menentukan metode promosi yang akan dilakukan. Menentukan media promosi untuk sebuah usaha adalah suatu hal yang penting. Dengan metode promosi yang tepat maka kesempatan untuk mengenalkan produknya akan menjadi lebih luas. Komunikasi pemasaran memegang peranan yang penting dalam membentuk perilaku konsumen.

\section{Pendampingan Peserta Pelatihan Kegiatan Pengabdian Masyarakat}

Tahapan akhir dari proses pelatihan kegiatan pengabdian masyarakat ini adalah melakukan kegiatan pendampingan secara daring melalui WhatsApp Group. Peserta diberikan fasilitas untuk berkonsultasi dengan para mentor dan diperkenankan untuk sharing kepada sesama peserta pelatihan. Mereka dapat menyampaikan progress yang telah terlaksana tentang basic branding strategy. Tidak menutup kemungkinan pula, para peserta pendampingan ini mengalami kesulitan ketika merancang sebuah brand yang akan menjadi bidang usahanya.

Berdasarkan hasil diskusi dengan peserta pendampingan, calon-calon entrepreneur yang mengikuti pelatihan ini mampu untuk memahami konsep basic branding strategy dan mengatasi kendala yang mereka alami. Para peserta pendampingan pelatihan ini juga telah berhasil merancang, memetakan, dan mengaplikasikan materi basic branding strategy menjadi sebuah brand yang nyata dan siap bersaing di masyarakat.

\section{KESIMPULAN DAN SARAN}

Indonesia mempunyai beberapa permasalahan yang perlu diselesaikan, salah satunya yaitu permasalahan pengangguran yang angkanya relatif semakin meningkat tiap tahunnya, apalagi di 
masa pandemi Covid-19 ini. Oleh karena itu, diperlukan berbagai upaya dari pemerintah untuk mengentaskan permasalahan ini, salah satunya yaitu dengan diadakannya Program Kartu Prakerja. Sejak diluncurkannya Program Kartu Prakerja pada tanggal 11 April 2020 lalu, sudah ada lebih dari 8 juta orang yang mendaftar, beberapa di antaranya sudah lolos mendapatkan Kartu Prakerja dan memulai pelatihan. Akan tetapi, masih ada yang merasa kesulitan untuk memulai bekerja. Oleh karena itu, pengabdian masyarakat dengan memberikan pelatihan Branding Strategy tanpa biaya ini diadakan untuk membantu masyarakat dalam memulai memasarkan produknya yang berupa barang ataupun jasa. Karena produk yang memiliki pasar kecil memiliki peluang yang lebih besar untuk memasarkan produknya dengan lebih fleksibel.

Terdapat dua tahapan dalam pelaksanaan pengabdian masyarakat ini, yaitu proses pelatihan Branding Strategy dimana peserta mendapatkan materi strategi branding tentang marketing mix yang mencakup 4P (product, price, place, dan promotion) dan pendampingan peserta pelatihan setelah mendapatkan materi tersebut. Secara keseluruhan branding bukan hanya sebatas 4P tetapi juga termasuk pelayanan prima kepada pelanggan. Pelaksanaan pengabdian masyarakat ini diharapkan mendapatkan antusiasme yang tinggi dari masyarakat meskipun dalam pelaksanaannya dilakukan secara daring, tidak tatap muka, mengingat Indonesia masih di masa pandemi Covid19. Setelah pandemi, kami berharap pendampingan setelah pelatihan Branding Strategy dapat diadakan secara tatap muka agar lebih kondusif dan efektif.

\section{UCAPAN TERIMA KASIH}

Kami mengucapkan terima kasih kepada Jurusan Komunikasi Penyiaran Islam IAIN Syekh Nurjati Cirebon karena telah memberikan kesempatan untuk melaksanakan kegiatan ini dan kepada peserta yang telah bersedia mengikuti kegiatan pelatihan ini.

\section{DAFTAR PUSTAKA}

Ardi, H. A., Samsiah, S., Busyro, W., Sandri, S. H., Misral, M., \& Rahmayanti, S. (2017). Pemberdayaan Usaha Masyarakat Melalui Branding Produk. Jurnal Pengabdian UntukMu NegeRI, 1(2), 54-59. https://doi.org/10.37859/jpumri.v1i2.236

Kayode, O. (2014). Olujimi Kayode Marketing Communications.

Kitchen, P. J. (2002). Marketing Communications. Qualitative Market Research: An International Journal, 5(2). https://doi.org/10.1108/qmr.2002.21605bae.003

Kotler, P. (2003). Managemen Pemasaran Analisis, Perencanaan, Implementasi, dan Pengendalian. Edisi 5. Jilid 2. Jakarta: Prehalindo

Marius, J. A. (2004). Memecahkan Masalah Pengangguran di Indonesia. Bandung: IPB 
No Title. (n.d.).https://www.jurnal.id/id/blog/toko-offline-vs-online-kelebihan-kekurangannya/ Pitartono, R. (2012). Analisis Tingkat Pengangguran di Jawa Tengah Tahun 1997-2010. Ekonomi Pembangunan.

Prisgunanto, I. (2006). Komunikasi Pemasaran: strategi dan taktik. Bogor: Ghalia Indonesia, 8287.

Sapienza, Z. S., Iyer, N., \& Veenstra, A. S. (2015). Reading Lasswell's Model of Communication Backward: Three Scholarly Misconceptions. Mass Communication and Society. https://doi.org/10.1080/15205436.2015.1063666

Lestari, S. P. (2015). Hubungan Komunikasi Pemasaran Dan Promosi Dengan Keputusan Memilih Jasa Layanan Kesehatan (Studi Pada Rumah Sakit Islam Lumajang). Jurnal Interaksi, 4(2), 139-147. https://doi.org/10.14710/interaksi,4,2,139-147

Sukirno, S. (2004). Makro ekonomi teori pengantar edisi ketiga. Jakarta: Raja Grafindo Persada. https://www.jurnal.id/id/blog/toko-offline-vs-online-kelebihan-kekurangannya/ https://www.prakerja.go.id 